v_m_vlas@ukr.net

\title{
ТЕАТРАЛЬНЕ МИСТЕЦТВО В СЕРЕДОВИЩІ МІЖВОСННОЇ УКРАЇНСЬКОЇ ПОЛІТИЧНОЇ ЕМІГРАЦІЇ В ЮГОСЛАВІЇ
}

У статті на основі чеського, українського і сербського архівів та української емігрантської преси висвітлено театральне мистецтво української політичної еміграції в Югославії в період між Першою та Другою світовими війнами. Визначено, що організаторами вистав були українські театральні товариства, громадські організації та їхні підрозділи (театральні гуртки, секції, аматорські трупи). Охарактеризовано репертуар та склад театральних труп. Акцентовано увагу на участі професійних театральних акторів та відомих громадських діячів у діяльності театральних труп.

Ключові слова: вистава, комедія, опера, п’єса, театр, трупа, українська еміграція, Югославія.

Міжвоєнна українська еміграція в Королівстві сербів, хорватів і словенців (КСХС, з 1929 р. - Югославія) - складне суспільне явище. У даній статті йдеться не про всю тогочасну еміграцію, а лише про політичну, тобто ту їі частину, яка була політично вмотивованою, ідеологічно визначеною, організаційно структурованою та сповідувала ідею української національної державності в будь-якій іiі формі. У науковій літературі вже знайшли висвітлення такі питання 3 досліджуваної теми, як російська й українська еміграція в Югославії (Козлитин, 1996), хвилі еміграції (Румянцев, 2008, Власенко, 2014, 2015), натуралізація емігрантів (Власенко, 2018b), їхнє правове становище (Власенко, 2019c), відносини еміграції з владою (Власенко, 2019a), іiі громадські організації (Козлитин 1996, Власенко 2011a, 2011b, 2017, Гула, 2018), політичні організації (Власенко, 2016), відзначення еміграцією національних свят (Власенко, 2012), культура, освіта та наука в емігрантському середовищі (Власенко, 2018a, Власенко, 2019b). Поза увагою дослідників залишилися питання діяльності еміграції на ниві театрального мистецтва. Саме тому автор ставить за мету охарактеризувати театральне мистецтво в середовищі міжвоєнної української політичної еміграції в Югославії. 
Культурні заходи української еміграції у КСХС/Югославії, як порівняти з іншими балканськими країнами, мали певну специфіку. 3 одного боку, політичні емігранти тією чи іншою мірою брали участь у культурному житті русинсько-української меншини в цій країні, 3 другого, до складу Українського товариства Просвіта (УТП) в Загребі належало чимало філій, серед членів яких переважали представники русинсько-української меншини. Зауважимо, що у 1919 р. у м. Прнявор з ініціативи тамтешніх українців Василя Стрільчика, Андрія Біленького, Стефана Грицая, Василя Семяка та греко-католицького священика Михайла Кіндія було засновано перший український драматичний гурток у КСХС, який іноді називали аматорським. На Томину неділю у великій залі готелю Поповича відбулася прем'єра комедії Сватання на Гончарівиі Г. Квітки-Основ'яненка. Серед глядачів - серби й українці. Невдовзі до групи долучилися й емігранти з Наддніпрянської України. У січні 1921 р. на свято Богоявлення гурток представив драму Верховиниі Й. Корженьовського. Режисер і виконавець головної ролі (Антон) - емігрант Микола Брояковський. До 1926 р. у Прняворі та Вучіяку драматичний гурток представив п’єси Наталка Полтавка I. Котляревського, Сава Чалий І. Карпенка-Карого та Невільники М. Кропивницького. Виявили себе на театральній сцені члени гуртка Андрій Біленький, Олександра Романчук, Ярослав Фарина, Наталка Юриста, та інші. Згодом режисером історичної драми Маруся Богуславка М. Старицького виступив А. Біленький (Юриста, 1925: 178180).

На ниві сценічного мистецтва серед русинсько-української меншини виявив себе професійний актор і режисер Петро Різніч (Дядя), який у 1919 р. емігрував до Югославії. Він очолив театральну аматорську трупу у Старому Вербасі (Рамач, 2016: 12). Поставив комедію Шутка (1931), п'єси На сінокосі, Хмара О. Суходольського (1923), Запорозький скарб К. Ванченка-Писанецького (1935). На думку сербського історика Л. Хайдуковича, у міжвоєнний період найбільшою популярністю серед аматорів русинської меншини користувалися вистави Наталка Полтавка І. Котляревського, Весілля М. Гоголя, Назар Стодоля Т. Шевченка, Учитель I. Франка, Ой, не ходи Грицю, та й на вечорниці М. Старицького, Як ковбаса та чарка, то минеться й сварка М. Кропивницького, Безталанна I. Тобілевича, Сватання на Гончарівиі Г. Квітки-Основ'яненка (Хајдуковић, 2007: 166-167). 
У 1925 р. УТП в Загребі вперше як організація влаштувала концерт на честь Т. Шевченка. Його вокальну частину через брак власних музичних сил виконав один із найкращих загребських хорів Branimir під орудою прихильника української пісні Вілька Петровича. Глядачі почули у виконанні хору й оркестру уривки 3 опери Запорожещь за Дунаєм С. Гулака-Артемовського - увертюру і Хор украйнців, пісні Ой, щось дуже загулявся й Звідкіля ти взявся, арію Султана, молитву і фінал опери. Солісти - українець з Кубані, артист Загребської опери, член Просвіти Анатолій Майлушевський (тенор) та хорватський артист П. Петрович (бас) (NAČR: 964). Відгуки на концерт були опубліковані на сторінках місцевих газет Hrvat, Hrvatsko Pravo, Narodni Politika, Obzor тa Slobodna Tribuna (Г., 1925: 4).

Після переведення централі УТП до Белграда загребська філія не виявила великої активності в культурній галузі. Її члени взяли участь у IV Вечорі слов'янських імпрез, що проходив у Народному театрі (Тушканац), представивши музичну комедію Різдвяна ніч М. Старицького за повістю М. Гоголя (Хорив, 1943: 5-6).

Філії загребської Просвіти, у складі яких переважали представники русинсько-української меншини, ставили українські п’єси. Так, у Лішні зусиллями місцевих просвітян були представлені п’єси Невільники (1933), Сватання на Гончарівці (1934) Турецькі старости (1936), Камениці - Пташка щастя і Свідки (1934), У тієї Катерини (1937), Козарці - Заручники по смерті (1934), Прняворі Запорожець за Дунасм (1934), Давно те діялося (1936), Правдиве багатство (1937), Різдвяна ялинка (1939), Муїнцях - Трьох до вибору та Фесько Ганжа Андибер (1936), Хорвачанах - Козаџька любов (1936), Штрбцях - Галя (1936), Слово як горобець, Мертві воскресають (1937), Гаєві - Арендар в клопоті (1937) (Ліський, 2008: 71-72; Liskij, 2008: 6066). Часто організаторами культурних акцій філій УТП виступали студенти-українці Загребського університету. Так, Андрій Пелих поставив драму Назар Стодоля Т. Шевченка. Акторами виступила шкільна молодь (Liskij, 1990-2000: 296-297).

Після перенесення централі УТП із Загреба до Белграда культурне життя української еміграції в столиці пожвавилося. Влітку 1926 р. при белградській Просвіті утворився аматорський драматичний гурток у складі 3. Борисполець, П. і О. Волишиних, Т. Дударевої, І. Ноги, О. Салікова, О. Собринської, Кушніренко, Щербак та інших. 
Керівник гуртка - Михайло Манглер, диригенти хору - Олексій Гриньков і Степан Красутський. У 1927 р. відбувся перший публічний виступ УТП в Белграді. Гурток поставив одноактні п’єси На перші гулі С. Васильченка і Кум-мірошник Д. Дмитренка (В. А., 1930: 19). У березні та травні 1929 р. на розсуд української та сербської громадськості белградська Просвіта представила п’єсу Невольник I. Карпенка-Карого. На прем’єрі були присутні заступник міністра внутрішніх справ Жика Лазіч, урядовці Міністерства освіти, Посол Польщі в КСXC Wactaw Babiński, керівники і вчителі місцевих гімназій, військові, журналісти та громадськість (Українське, 1929: 41; ЦДАГО, 269-2-273: 8). Режисер вистави - М. Манглер, помічник режисера - А. Ільченко, адміністратор - I. Ніколаєнко, художник - П. Трунов, диригент - С. Красутський, акомпаніатор - Б. Пушин. Роль Василя Коваля виконав Ришкевич, Ярини - Т. Дударева, Степана - I. Хрипак, Оксани - К. Дударева, Недобитого (бандурист) - 3. Борисполець, Опари - I. Нога, Голощука - Ложченко, Недорізаного - Сивак, Покришки Щербак, Неплюя - П. Волошин, Кукси - С. Красутський, Подорожнього - Гречишкин, Зачепи - Федота, Джури - Куценко, Поводиря незрячого - Н. Бабенко (ЦДАГО, 269-2-271: 172).

Згодом поставили п'єсу Хмара О. Суходольського. У другій половині 1929 р. при УТП в Белграді діяла нова театральна трупа у складі 3. Борисполець, П. Волошина, Т. Дударєвої, І. Ноги, О. Собрівської, Н. Хохлець, Ф. Федька ті інших, яка дебютувала постановкою оперети Сватання на Гончарівиі Г. Квітки-Основ'яненка (Козлітін, 1996: 62).

Філія УТП у Новому Саді, яку на той час очолював полковник О. Колтоновський, також самотужки влаштовувала вистави. Так, 7 грудня 1929 р. члени Просвіти поставили п’єсу Сватання на Гончарівиі (3 життя, 1930: 27).

Різноманітною була культурна діяльність Української громади (УГ) в Белграді. Спочатку через брак культурних діячів програми таких заходів були скромними, але полім урізноманітнилися. Так, 5 грудня 1931 р. на вечорниці були представлені комічні монологи 3 п’єс у виконанні О. Волошиної, В. Зіверт, В. Андрієвського, П. Волошина та К. Цвітановича. В одноактному жарті Ходімте у Громаду, спеціально написаному для цієї вечорниці, ролі зіграли Л. Добровицька, В. Зіверт, О. Демиденко та М. Хляченко (Товариські, 1931: 43). До участі у 
вечорницях долучалися нові люди - колишня артистка Київської опери М. Колесникова зі своїми помічниками-аматорами Т. Роговою, I. Удовицьким і Г. Бараненком та бандурист А. Чорний (Товариські, 1932: 12-13).

На вечорницях члени УГ в Белграді пробували свої сили й у сценічному мистецтві. Ставили жарти на 1 дію Оказія з пампушкою та Як вона може любить (1936р.) (Товариські, 1936: 12; 3 життя, 1936: 23), одноактні водевіль Бувальщина, в якому головні ролі виконали А. Балабан, Г. Дніпрова, П. Волошин, М. Річицький та І. Христак, і п’єси За кулісами театру та Кум-мірошник (1937 р.) (3 життя, 1937: 31; Товариські, 1937: 47).

Для постановки вистав УГ в Белграді започаткувала драматичну секцію. 6 квітня 1930 р. у залі Чехословацького Дому вона представила комедію Миротвориі Б. Гринченка, оперету Кум-мірошник, гротеск $3 a$ кулісами В. Некрашевича. Ролі виконували аматори (Українська, 1930: $30)$.

У 1933 р. УГ в Белграді влаштувала 2 вистави. 18 лютого була представлена комедія Пошилися в дурні М. Кропивницького, 1 квітня п’єси На перші гулі С. Васильченка та Вечорниці П. Ніщинського. Режисером цих вистав виступила М. Колесникова, ролі виконали Н. Голубова, В. Зірка, М. Михайленко, Г. Покровська, П. Харченко, П. Волошин, П. Загребельний, П. Махров, М. Міхно, І. Удовицький та I. Хрипак (Українська, 1933: 14).

Один із керівників УГ в Белграді В. Андрієвський на сторінках емігрантської преси писав, що, враховуючи необізнаність сербської публіки з українською культурою та велику кількість малоросів серед російських емігрантів, між якими за допомогою українського театру можна було б успішно вести розмосковлення, потреба в українському театрі в Белграді відчувалася гостро. До того ж, оренда театральних приміщень передбачала великі матеріальні витрати. Тому наприкінці 1934 р. управа УГ винайняла просторе приміщення, в якому влаштувала розкладну сцену, i 1 грудня театральна секція при Громаді дала першу виставу $У$ miєї Катерини Я. Мамонтова. Завдяки зусиллям родини Доброхотових вистава пройшла з успіхом (Українська, 1935: 26-27).

До квітня 1935 р. художньо-драматична секція під проводом Г. Доброхотової (Дніпрової) представила 4 вистави. Остання серед них драма Наймичка I. Карпенка-Карого. Роль Харитини виконала Г. 
Доброхотова, Мелашки - Г. Бабушкина, Цокуля - П. Волошин, Панаса А. Варивода, Баруха (Бороха) - М. Задорожний, грали також Т. Хмара та М. Букин (А., 1935: 25-26). У жовтні того ж року секція представила п’єсу Назар Стодоля Т. Шевченка з Вечорнииями П. Ніщинського. Роль Галі виконала Г. Доброхотова, Хоми - Ришкевич, Назара - Богров, господарки на вечорницях - Спаховська, Стехи - Плотницька, Гната А. Варивода. Дві ролі зіграв М. Задорожний. Хором керував П. Загребельний (Вистава, 1935: 12).

Невелика за розмірами сцена для театральних вистав у приміщенні УГ в Белграді дозволяла грати одноактні п'єси. 5 березня 1937 р. на товариській вечірці з нагоди 20-річчя артистичної діяльності П. Волошина були представлені одноактні п'єси По ревізії та Миротвориі, в яких ювіляр зіграв головні ролі (ЦДАГО, 269-2-283: 99). 18 грудня 1937 р. артистичні сили Громади поставили комедію Мартин Боруля І. Карпенка-Карого. Уміла режисура професора М. Чубинського та мистецьке виконання ним ролі Мартина Борулі сприяли тому, що і на малій сцені вистава у 5-ти діях пройшла з успіхом. Ролі виконали О. та П. Волошини, Г. Доброхотова, М. Задорожний, С. Заполенко, Й. Прокопюк, М. Рігицький, В. Рибальський та М. Хляченко. Оскільки не всі бажаючі змогли подивитися виставу, громада ії показала вдруге (ЦДАГО, 269-2-283: 7-7зв, 52зв).

У червні 1938 р. у власному приміщенні УГ в Белграді були представлені одноактні п'єси Оказія з пампушкою, Хірургія та Мале непорозуміння, вересні того ж року - комедія на 3 дії Панна Штукарка А. Володського. У виставі взяли участь О. Волошина, В. Доможирова, М. Демиденко, Г. Михайличівна, А. Сидоренко, П. Волошин, М. Задорожний, С. Заполенко, М. Качан, Й. Прокопюк та В. Рибальський (Українська, 1938: 17). 15 жовтня 1938 р. при відзначенні 10-літнього ювілею УГ була поставлена одноактна п'єса Небезпечне товариство, в якій ішлося про українське емігрантське середовище в Белграді (Анський, 1939: 9).

Крім белградських Просвіти і Громади театральним мистецтвом займалися українські драматичні гурток, трупа та товариство. 3 літа 1929 р. у Белграді діяло Українське драматичне товариство на чолі із М. Праведниковим. 2 листопада того ж року воно поставило оперету Наталка Полтавка (ЦДАГО, 269-2-275: 5). Але невдовзі товариство припинило існування. У 1930 р. В. Андрієвський на сторінках Тризуба 
виклав історію української театральної справи в Белграді. Непорозуміння між окремими театральними угрупованнями вплинули на роз'єднання місцевих українських мистецьких сил. Почалися недобросовісна конкуренція й інтриги, що призвели до зменшення інтересу публіки до вистав.

19 жовтня 1930 р. відбулися установчі збори Українського художньо-драматичного товариства (УХДТ), до якого записалося близько 70 осіб. Було прийнято статут й обрана управа у складі М. Баскевича (голова), М. Праведникова (заступник), О. Зіверта (секретар), В. Андрієвського (скарбник), М. Манглера (режисер), П. Загребельного (диригент), Миколаєнка (адміністратор), Я. Ноги, Бакуревича та проф. Петровича (члени). 9 травня 1931 р. у великій залі Зграда Радничке коморе УХДТ показала оперу Запорожеиь за Дунаєм С. Гулака-Артемовського. Режисер-постановник - М. Колесникова, актори - Є. Мозгова, М. Семененко, Мирославський. Але у трупі мало було членів УХДТ. Поступово зі складу Товариства вийшли свідомі українці. Місцем його перебування став Російський офіцерський дім. У лютому 1932 р. М. Колесникова поставила оперету Наталка Полтавка, яку українська преса оцінила негативно (частина акторів не знала української мови) (Вистава, 1932: 26). Невдовзі УХДТ самоліквідувалося, а наприкінці 1934 р. відновило свою діяльність. В березні 1935 р. у приміщенні Коларчева університету представило оперу Запорожець за Дунаєм С. Гулака-Артемовського. Режисер - М. Манглер, диригент - Н. Васильєв, хормейстер - О. Гриньков, постановник українських народних танців - А. Жуковський (Запорожец, 1935: 13).

У квітні 1935 р. змінилося керівництво УХДТ. Його очолив колишній секретар белградської Просвіти 3. Борисполець. До управи товариства увійшли представники націоналістичного напрямку УГ в Белграді (В.А., 1935: 26 ). Невдовзі воно поставило опери Запорожещь за Дунаєм та Наталка Полтавка.

Відомим театральним діячем в емігрантському середовищі був Михайло Манглер (Михайлович). Свого часу він очолював драматичні колективи УТП та УГ в Белграді, у другій половині 1930-х рр. приватний театр й одночасно Українське просвітнє музично-співоче товариство. Свою професійну діяльність актора він розпочав у 1892 р. в Українсько-російському театрі, 1900-1918 pp. був керівником 
Народного театру в Оренбурзі (АЈ 66-359-597: Украјинско). Потім емігрував до КСХС. У другій половині 1930-х рр. кілька разів ставив на белградській сцені оперу Запорожеиь за Дунаєм (АЈ 66-359-597: Министарство).

На ниві сценічного мистецтва відзначилася невелика група українців і кубанських козаків у м. Смедерево. На початку 1926 р. вона заснувала Український аматорський гурток, який влітку 1931 р. був легалізований як Українська громада Кобзар. Спочатку група брала участь у місцевих культурних акціях 3 невеликими номерами (пісні, танці), час від часу давала вистави. На початок 1929 р. мала тексти п'єс Наталка Полтавка I. Котляревського, Назар Стодоля Т. Шевченка, Безталанна і Наймичка I. Карпенка-Карого, Ой не ходи, Грицю М. Старицького, Хмара О. Суходольського, По ревізї і Пошилися в дурні М. Кропивницького, Бориі за мрї і Жидівка-вихрестка І. Тогобочного, Нещасне кохання Л. Манька, Ясні зорі Б. Грінченка, Хоч раз його правда Г. Марусина, Мотря Кочубеївна Ф. Крушинського, Ведмідь А. Чехова, Сини народу, Свідки, а також опери Запорожець за Дунаєм С. ГулакаАртемовського (ЦДАГО, 269-2-271: 83-83зв). Упродовж усього міжвоєнного періоду представник військового міністра УНР на Балканах В. Филонович надсилав керівнику гуртка Пилипу Чорному не тільки тексти п'єс, але і партитури до них (ЦДАГО, 269-2-275: 10зв, 85).

Вперше великий розголос серед місцевої сербської публіки викликала вистава Невольник I. Карпенка-Карого. Вона відбулася 16 березня 1929 р. у великій залі будинку Державних залізничних майстерень. 3 дозволу керівника підприємства приміщення їдальні переобладнали під театральну залу на 380-400 місць. Лібрето сербською мовою написав П. Чорний. Режисер - професійний актор Іван Коробко. Вщент заповнена зала не вмістила всіх бажаючих, тому наступного дня група $з$ таким же успіхом вдруге зіграла п’єсу (ЦДАГО, 269-2-272: 21$213 в)$. Оскільки частину аматорського гуртка складали кубанські козаки, то замітку про виставу і фото артистів було опубліковано на сторінках журналу Вольное казачество - Вільне козацтво (ЦДАГО, 269-2-275: 147). 16 грудня того ж року там же гурток представив п'єсу Хмара О. Суходольського. Завдяки старанням режисера I. Коробка, художникааматора Б. Жижиленка, керівника групи П. Чорного (суфлер) та Соколова вистава мала великий успіх. На прохання місцевої публіки п’єсу показали і наступного дня (Смедерево, 1930: 29). 
Станом на 1 серпня 1931 р. Український аматорський гурток представив на розсуд глядачів п'єси Невольник (4 рази), Хмара, Різдвяна ніч, Вечорниці, Наталка Полтавка, Кум-мірошник та низку одноактних вистав (Українець, 1931: 44). 3 метою зацікавлення українським мистецтвом місцевого сербського глядача П. Чорний переклав на сербську мову низку п'єси. Гурток мав успіх не тільки у Смедерево. Його запрошували до Ковіна, Модоша (нині Яша Томіч), Пожаревца та інших міст (ЦДАГО, 269-2-272: 90).

Українське театральне мистецтво демонструвала й Українська громада у Великому Бечкереку. У грудні 1930 р. голова управи УГ М. Мельничук ініціював постановку української вистави сербською мовою. В одному $з$ провінційних театрів вдалося знайти переклад п'єси М. Старицького Ой не ходи, Грицю (На поселу) на сербську мову, а сотник С. Горячко з української станиці в Каліші (Польща) надіслав партитуру. Сербський Сокольський театр, в якому грали члени управи громади М. Мельничук і С. Третевич, взявся за справу. Для вистави було виготовлено декорації, залучено сокольські оркестр, чоловічий хор та місцеве Співоче церковне товариство. Костюми для постановки надали українські громади Белграда та Смедерева. Режисер вистави - М. Мельничук, диригент - о. Михайло Шипош. 8 січня 1933 р. замість урочистої сокольської академії відбулася вистава, яка мала великий успіх. Вона позитивно вплинула на пропаганду української справи серед місцевого населення. Саме тоді серби заговорили про Україну, українців, українську культуру й окремішність українців від росіян (Великий Бечкерек, 1933: 58). Вистава користувалася великим попитом у місцевого населення, тому ії̈ ставили неодноразово.

На ниві театрального мистецтва в Югославії відзначилися відомий режисер Юрій Шерегій і частина його трупи театру Нова сцена, які після окупації Угорщиною Закарпаття у березні 1939 р. змушені були емігрувати (Хајдуковић, 2007: 167). На початку квітня того року на запрошення редактора часопису Руски новини о. М. Фірака з міста СатуМаре вони відбули до Югославії. Актори трупи Олена Ватько, Олена Павлюк, Іван Ощудляк та редактор журналу Нова сцена Орест Чернєк прибули до Югославії дещо раніше. Невдовзі при РНПД в Руському Керестурі була створена театральна трупа. До її складу увійшли кілька членів Нової сиени й артистів-аматорів із Закарпаття та місцеві любителі-театрали. Керівник трупи - місцевий диригент Іриней Тимко, 
танцмейстер - Олена Павлюк, режисер - Ю. Шерегій. 23 квітня у будинку РНПД відбулася прем'єра вистави Запорозький скарб К. Ванченка-Писанецького. Роль Герасима Буца виконав артист Нової сцени Микола Петришин, Галі - Наталка Сабол із Р. Керестура, Леска Мокрого - учитель із Західної України Ілько Зварич, Федули Зачепи Ю. Шерегій, цигана Вацка - Іван Ощудляк, Груні - Ольга Петригала 3 Р. Керестура, танцювала Олена Ватько. 26 квітня оперету представили вдруге (Шереги, 1967a: 61-63).

20 травня 1939 р. в Руському Керестурі відбулася прем'єра комедії Сорочинський ярмарок М. Старицького, 28 травня - у м. Півніце (Пивнище). Замітки про виставу опублікували паризький тижневик Українське слово (18.05.1939) та словацька газета Národná jednota (19.06.1939) (Шереги, 1967a: 68-70). 18 і 19 червня того ж року у Державному театрі м. Осієк театральна трупа на чолі із Ю. Шерегієм показала ці ж вистави місцевій публіці. Позитивні рецензії на них 3'явилися на сторінках газет Hrvatski list (20.06.1939), Руски новини (23.06.1939) та Рідне слово (25.06.1939). До листопада 1939 р. місцеві глядачі побачили поставлені Ю. Шерегієм оперету Сорочинський ярмарок, драму Хмара, його власні п'єси На порозі охрещення Русі, Чорний братчик, Невінчані та Пан. Деякі 3 них були представлені глядачам у Коцурі та Міклошевцях (Шереги, 1967b: 135-138).

Переїхавши до м. Шид у Хорватії, Ю. Шерегій разом 3 місцевими аматорами поставив у Руській читальні та читальні РНПД п’єси Хмара, Наталка Полтавка та Пан. За 7 місяців перебування в Руському Керестурі театральна група на чолі з Ю. Шерегієм поставила 10 спектаклів, в тому числі 4 прем'єри, у Шиді - ще більше імпрез (Шереги, 1967c: 219-221). У вересні 1940 р. Ю. Шерегій переїхав до Праги.

Зауважимо, що українські п'єси ставили також театральні трупи кубанських козаків. Так, 23 листопада 1929 р. у театральній залі готелю Париж м. Шабац аматорський гурток місцевої козацької станиці поставив українською мовою п'єсу Тарас Бульба за однойменною повістю М. Гоголя. На прохання публіки через декілька днів іiі представили вдруге. Козацька емігрантська преса позитивно оцінила роботу аматорів сцени (Косенко, 1930: 20-21).

Отже, міжвоєнна українська політична еміграція в Югославії широко розвинула культурну діяльність. Ї̈̈ громадські організації мали 
власні театральні аматорські трупи або гуртки, які представляли емігрантській і сербській публіці не тільки вистави (драми, комедії, опери, оперети), але й імпрези, уривки 3 вистав на вечорницях, концертах, шевченківських святах, під час відзначення державних i релігійних свят, ювілеїв історичних подій або постатей. Іноді режисерами, постановниками вистав й акторами виступали професійні митці, а також відомі громадські діячі, зокрема Михайло Чубинський. Перспективними, на погляд автора, $є$ дослідження діяльності української еміграції на ниві образотворчого і музично-танцювального мистецтва та літератури в Югославії.

\section{ДЖЕРЕЛА}

Arhiv Jugoslaviji (AJ), f. 66, fasc. 359, j. o. 597: Ministarstvo prosvete, opšte odeljenje, prispeo broj 10572, 22 marta 1938.

AJ, f. 66, fasc. 359, j. o. 597: Ukrajinsko umetničko-dramsko društvo, uverenje, 25. februara 1932.

Central'nyj deržavnyj arxiv hromads'kyx ob'jednan' Ukrajiny (CDAHO, f. 269, op. 2, spr. 271.

CDAHO, f. 269, op. 2, spr. 272.

CDAHO, f. 269, op. 2, spr. 273.

CDAHO, f. 269, op. 2, spr. 275.

CDAHO, f. 269, op. 2, spr. 283.

Národní archiv Česke republike (NAČR), f. «Ukrajinske muzeum v Praze», kart. 81, inv. № 964.

Šeregi JU. A. (1967a). Ukrajinski teatralni predstavi, kursi ukrajinskih narodnih tancoh i druhi impresiji u Bački y Srime 1939-1940. rok (I). Švetlosc, 1, 61-70.

Šeregi JU. A. (1967b). Ukrajinski teatralni predstavi, kursi ukrajinskih narodnih tancoh i druhi impresiji u Bački y Srime 1939-1940. rok (II). Švetlosc, 2, 131-138.

Šeregi JU. A. (1967a). Ukrajinski teatralni predstavi, kursi ukrajinskih narodnih tancoh i druhi impresiji u Bački y Srime 1939-1940. rok (III). Švetlosc, 3, 217-223. 


\section{ЛІТЕРАТУРА}

A. (1935). Ukrajins'ka vystava v Bilhorodi. Tryzub, 17-18, 25-26. (Cirillic). Ans'kyj V. (1938). Ternystym šljahom (Desjat' rokiv Ukrajins'koji Hromady v Bilhorodi). Tryzub, 46, 7-9. (Cirillic).

G. (1925). Dopysi. Zagreb, 16. IV. 1925. Ukrajins 'kyj prapor, 9, 4.

Hajduković L. (2007). Pozorišno tvorenje naših Rusina. Zbornik Matice srpskoj za scenske umetnosti i muziku, 36, 161-173. (Cirillic).

Horyv. (1943). Ukrajins'ka emihracija v JUhoslaviji (zakinčennja). Ukrajins'kyj visnyk, 3 (102), 3-7.

JUrysta M. (1925). Ukrajins'kyj «dramatyčnyj kružok» v Prnjavori. Ruski kalendar za južno-slavjanskih rusinoh na 1926 rok. 178-180. (Cirillic).

Kosenko A. (1 janv. 1930). Hronika kazač́ej žizni za rubežom. Kavkazskij kazak (informacija), str. 20-21. (Cirillic).

Kozlitin V.D. (1996). Russkaja i ukrainskaja èmigracija v Jugoslavii (19191945 gg.). Har'kov : RA.

Kozlitin V. (1996). Ukrajins'ki gromads'ki orhanizaciji v JUhoslaviji (20-30ti rr. XX st.). Ukrajins'ka diaspora, 9, 52-69. (Cirillic).

Liskij B. (1990-2000). Filijale zagrebačkoh društva Prosvita u Šumeću i Kanjiži. Думки з Дунаю = Misli s Dunava, 3, 294-298.

Lis'kyj B. (2008). Ohljad kul'turno-osvitn'oho žyttja ukrajinciv u Bosniji (1890-1990). Materialy do istoriji ukrajinciv u Bosniji. T. 5 / Uporjad. i red. o. dr Roman Myz'. Novyj Sad. 71-76. (Cirillic).

Liskij B. (2008). Djelovanje ukrajinskoh društva «Prosvita» iz Zagreba među Ukrajincima u Bosni i Hercegovini između dvaju ratova. Materialy do istoriji ukrajinciv u Bosniji. T. 5 / Uporjad. i red. o. dr Roman Myz'. Novyj Sad. 60-66.

Ramač JA. (2016). Ohljad istoriji rusyniv u JUhoslaviji (1918-2000). Sums'ka starovyna, XLIX, 5-22. (Cirillic).

Rumjancev O.JE. (2008). Halyčyna - Bosnija - Vojevodyna : ukrajins'ki pereselenci z Halyčyny na terytoriji juhoslavs 'kyx narodiv v 18901990 rokax. Kyjiv : FADA LTD. (Cirillic).

Smederevo. (1930). Tryzub, 8, 29. (Cirillic).

Tovarys'ki večernyci. (1931). Tryzub, 49-50, 43. (Cirillic).

Tovarys'ki večernyci. (1932). Tryzub, 23, 12-13. (Cirillic).

Tovarys'ki večernyci v Bilhorodi. (1936). Tryzub, 37, 12-13. (Cirillic). 
Tovarys'ki večernyci. (1937). Tryzub, 47, 27. (Cirillic).

Ukrajinec'. (1931). Ukrajins'ka Hromada «Kobzar»u Smederevi. Tryzub, 29-30, 44. (Cirillic).

Ukrajins'ka vystava. (1930). Tryzub, 18, 30. (Cirillic).

Ukrajins'ka vystava. (1933). Tryzub, 20, 14. (Cirillic).

Ukrajins'ka vystava v Bilhorodi. (1935). Tryzub, 10, 26-27. (Cirillic).

Ukrajins'ka vystava. (1938). Hurtujmosja, 3 (XXIV), 17. (Cirillic).

Ukrajins'ke T-vo «Prosvita» v Bilhorodi. (1929). Tryzub, 16-17, 41. (Cirillic).

V. A. (1930). Ukrajins'ka teatral'na sprava v Bilhorodi (Lyst iz JUhoslaviji). Tryzub, 43, 19-20. (Cirillic).

V. A. (1935). Zminy v Xudožnje-Dramatyčnomu Tovarystvi. Tryzub, 17-18, 26. (Cirillic).

Velykyj Bečkerek. (1933). Hurtujmosja, X, 58. (Cirillic).

Vystava «Natalky Poltavky». (1932). Tryzub, 11, 26. (Cirillic).

Vystava «Nazara Stodoli» u Bilhorodi. (1935). Tryzub, 43, 12. (Cirillic).

Vlasenko V. (2011a). Ukrajins'ka hromada u Belhradi u mižvojennyj period (za materialamy paryz'koho «Tryzuba»). Kyjivs'ka starovyna, 1, 123-136. (Cirillic).

Vlasenko V. (2011b). Ukrajins'ka hromada u Velykomu Bečkereku (JUhoslavija) u mižvojennyj period. Kyjivs'ka starovyna, 3, 41-48. (Cirillic).

Vlasenko V. (2012). Ševčenkivs'ki svjata mižvojennoji ukrajins'koji emihraciji v JUhoslaviji (za materialamy paryz'koho tyžnevyka «Tryzub»). Veličina malih jezičkih, književnih, kulturnih $i$ istorijskih tradicija : zbornyk radova. Novy Sad : Fylozofsky fakultet. 95-105. (Cirillic).

Vlasenko V. (2014). Formuvannja mižvojennoji ukrajins'koji polityčnoji emihraciji v JUhoslaviji (perša hvylja). Naukovi praci istoryčnoho fakul'tetu Zaporiz'koho nacional'noho universytetu, XXXIX, 85-91. (Cirillic).

Vlasenko V. (2015). Tretja hvylja mižvojennoji ukrajins'koji emihraciji do JUhoslaviji. Rusynystyčny studyji = Ruthenian studies : elektronsko izdanje / Univerzitet u Novim Sadze; glavni redaktor Julijan Tamaš. Novi Sad. 103-132 [elektronski optički disk (CD)]. (Cirillic).

Vlasenko V. (2016). Do istoriji Ukrajins'koho fašysts'koho zdvyhu v JUhoslaviji. Osobystist', suspil'stvo, deržava: problemy mynuloho $i$ 
s'ohodennja: materialy II Mižnar. nauk.-prakt. konf., m. Sumy, 18 kvitnja 2016 r. : u 2-x č. Sumy : SumDU. Č. 1, 83-87. (Cirillic).

Vlasenko V. (2017). Ukrajins'ke tovarystvo Prosvita v Zagrebi u 1922-1941

rr. (orhanizacijna struktura). Rusynystyčny studyji, 1, 97-112. (Cirillic). doi 10.19090/rs.2017.1.97-112

Vlasenko V. (2018a). Biblioteky i kluby ukrajins'koji polityčnoji emihraciji na Balkanah u mižvojennyj period. Rusynystyčny studyji, 2, 188-199. doi 10.19090/rs.2018.2.188-199

Vlasenko V. (2018b). Naturalizacija mižvojennoji ukrajins'koji polityčnoji emihraciji v Rumuniji ta JUhoslaviji. Pravovi horyzonty, 9 (22), 7 12. (Cirillic). doi 10.21272/legalhorizons.2018.i9.p7

Vlasenko V. (2019a). Mižvojenna ukrajins'ka polityčna emihracija v JUhoslaviji: vidnosyny z vladoju. Ukrajina dyplomatyčna, XX, 132140. (Cirillic).

Vlasenko V. (2019b). Osvita i nauka v seredovyšči ukrajins'koji polityčnoji emihraciji v JUhoslaviji. Nad Wista i Dnieprem. Polska i Ukraina w przestrzeni europejskiej - przeszłość i teraźniejszość. Monografia zbiorowa / red. Ihor Sribnyak. Warszawa-Toruń: Międzynarodowy konsorcium naukowo-edukacyjny im. Luciena Febvra. 125-129. (Cirillic).

Vlasenko V. (2019c). Pravove stanovyšče ukrajins'koji emihraciji v mižvojennij JUhoslaviji. Reformuvannja pravovoji systemy $v$ konteksti jevrointehracijnyh procesiv: materialy III Mižnar. nauk.prakt. konf.: u 2 č. (m. Sumy, 23-24 travnja 2019 roku): SumDU. Č. 1. 6-10. (Cirillic).

Z žyttja našoji emihraciji. (1930). Tryzub, 3, 27. (Cirillic).

Z žyttja Ukrajins'koji Hromady v Bilhorodi. (1936). Tryzub, 43-44, 23-24. (Cirillic).

Z žyttja bilhorods'koji Hromady (1937). Tryzub, 15, 31. (Cirillic). «Zaporožec za Dunavom» (29 mart. 1935). Polytyka, str. 13. (Cirillic).

Valeriy Vlasenko

THEATRICAL ART AMOHG INTERWAR UKRAINIAN POLITICAL EMIGRATION IN YUGOSLAVIA

Summary

Based on the previously unknown documents and materials from the National Archive of the Czech Republic, the Central State Archive of Public Organizations of 
Ukraine and the Archive of Yugoslavia and Ukrainian emigrant press, the theatrical activity of Ukrainian political emigration in Yugoslavia during the period between the First and Second World Wars was characterized. The main organizers of theatrical performances were emigrant public organizations - the Ukrainian Partnership Prosvita (Zagreb, Belgrade) with its departments in the regions, the Ukrainian communities (partnerships) in Belgrade, Velikyi Bechkerek, Smederevo, as well as theatrical partnerships, amateur theater groups and troupes. The cast and repertoire of theatrical troupes were analyzed. Attention was paid to the participation in the production of performances of professional theatrical figures and artists Mikhail Mangler, Mikhail Pravednikov, Maria Kolesnikova, (director), Stepan Krasutsky (conductor), Anatolyi Maylushevsky (tenor), Petr Trunov (artist) and Evgenia Mozgovaya (actress), as well as public figures, in particular Mikhail Chubinsky (director and actor). The repertoire of Ukrainian troupes included not only one-act, but also multi-act plays, operas and operettas, dramas and comedies, scenes from plays and theatrical monologues. Usually theatrical performances were timed to national, state and religious holidays, anniversaries of historical events and persons. Theater art among the Ukrainian political emigration was one of the means of preserving national identity in a different ethnic, political and cultural environment.

Keywords: comedy, opera, performance, play, theater, troupe, Ukrainian emigration, Yugoslavia. 
